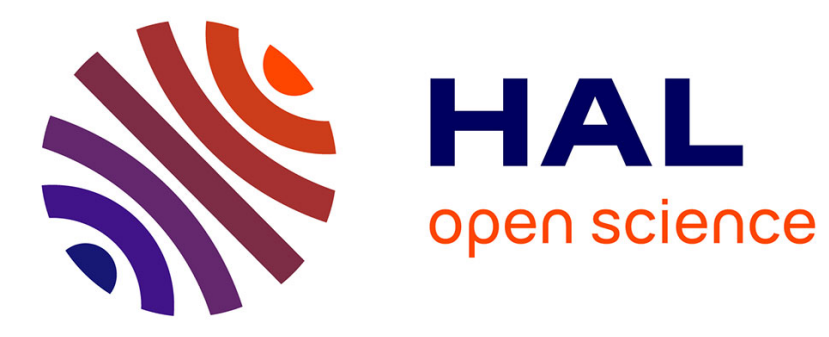

\title{
Philo on the Impermanence of Empires
}

Katell Berthelot

\section{To cite this version:}

Katell Berthelot. Philo on the Impermanence of Empires. Jonathan J. Price, Katell Berthelot. The Future of Rome: Roman, Greek, Jewish and Christian Visions, Cambridge University Press, p. 112129, 2020. hal-03078846

\section{HAL Id: hal-03078846 https://hal.science/hal-03078846}

Submitted on 8 Apr 2021

HAL is a multi-disciplinary open access archive for the deposit and dissemination of scientific research documents, whether they are published or not. The documents may come from teaching and research institutions in France or abroad, or from public or private research centers.
L'archive ouverte pluridisciplinaire HAL, est destinée au dépôt et à la diffusion de documents scientifiques de niveau recherche, publiés ou non, émanant des établissements d'enseignement et de recherche français ou étrangers, des laboratoires publics ou privés. 
Cambridge University Press

978-1-108-49481-6 - The Future of Rome

Edited by Jonathan J. Price, Katell Berthelot

More Information

CHAPTER 6

Philo on the Impermanence of Empires

Katell Berthelot

Reflections on empires among ancient writers can take different directions. Some focus on the succession of specific empires and speculate about the number of empires destined to rule the world, as does the author of the Book of Daniel, for example. ${ }^{\mathrm{I}}$ Such writers are in various ways concerned with history and how it continues from the past, through the present, and into the future. In some cases, this leads them to speculate about the end of time. ${ }^{2}$ Other authors are interested in comparing the empires of the past to the one(s) of their own day. In the Roman period, for example, many orators praise the Romans for establishing an empire that has surpassed all others. This type of comparison is not restricted to orations and can be found in various literary genres. Finally, there are writers who are prone to more philosophical reflections on empires and what causes their rise or decline, their intrinsic instability, or the political factors that help certain ones endure.

All these questions may be asked by a single author, though one generally expects a particular problem to dominate the work of any individual. Here, I shall examine whether and how these three lines of thought are present in Philo's work, starting in each case with a brief survey of discourses by ancient Greek writers such as Demetrius of Phalerum, Polybius, Dionysius of Harlicarnassus, Plutarch, Appian, and Aelius Aristides, albeit the last three were active only after Philo's death and, in the case of Appian and Aelius, extend into the second half of the second century CE. I shall then compare their discourses with that of Philo, in

\footnotetext{
I See Dn 2:31-35, 39-43. The ambiguity of this text allows for at least two interpretations: four or five empires could be alluded to. In a dream, the king sees a statue made of gold, silver, brass, iron, and a mixture of iron and clay, and Daniel interprets these materials as different kingdoms. The mixture of iron and clay could be interpreted as being a sub-part of the iron part, or as a distinct part and thus as a distinct kingdom.

2 See Chapter 9 by Vered Noam in this volume.
} 
Cambridge University Press

978-1-108-49481-6 - The Future of Rome

Edited by Jonathan J. Price, Katell Berthelot

More Information

\section{Philo on the Impermanence of Empires}

order to better appreciate the specificity of Philo's thought on empires and its implications for his understanding of the future of Rome.

\section{I Philo and the Greek Scheme of the Succession of Four or Five Empires}

\section{I.I From Herodotus to Appian}

By the fifth century, Greek historians such as Herodotus had developed a particular historical model that spoke of the succession of three different empires: that of the Assyrians, the Medes, and the Persians. In the wake of Alexander's conquests, the Macedonian Empire was added as the fourth great entity to the model. Later, when Rome overcame the Hellenistic kingdoms, it began appearing as the fifth great empire on the list. ${ }^{3}$

However, when referring to past empires and the way in which they succeeded one another, Greek writers did not necessarily follow the above order in every detail. Thus, at the beginning of his Histories, when discussing the ancient empires that bear comparison to Rome, Polybius refers to the Persians, the Macedonians, and the Lacedemonians (despite the fact that their dominion was limited to Greece), but not to the Assyrians or the Medes (Histories I.2.I-6). By contrast, when Dionysius of Halicarnassus similarly justifies his choice of topic - Roman history - by comparing Rome to previous empires, he follows the classical model of the four empires (Roman Antiquities I.2.I-4), while commenting on the hegemony of Athens, Sparta, and Thebes separately so as to emphasize that the comparison is not really relevant in their case (I.3.I-2). ${ }^{4}$ At the beginning of his Roman History, Appian likewise compares Rome to the ancient empires. First, he examines those of the ancient Greek states (Athens, Sparta, etc.), then those of the Assyrians, the Medes, the Persians, and the Macedonians (\$8). Lastly, when Aelius Aristides compares Rome to its predecessors, he basically follows the traditional model by stating:

\footnotetext{
${ }^{3}$ See Chapter 5 by Jonathan Price in this volume. Whether Greek and Roman authors considered Rome a fifth and everlasting empire in as early as the second century BCE, as a fragment of Aemilius Sura may attest, is debated. See Swain 1940, Mendels I98I (according to whom, the topos of Rome as the fifth empire became commonplace in Rome only in the second half of the first century BCE), and Alonso-Núñez 1989, who maintains that Aemilius Sura saw Rome as the fifth empire: "From the fragment of Sura we can deduce that one aim, maybe the most important, of his work De annis populi Romani was to glorify Rome's achievement in its expansive policy in the Mediterranean area and perhaps to predict for her an everlasting rule, though we have no elements in the fragment that allow us to state this plainly" (emphasis mine).

${ }^{4}$ For a different interpretation of this particular passage, see Jonathan Price's chapter in this volume.
} 
Cambridge University Press

978-1-108-49481-6 - The Future of Rome

Edited by Jonathan J. Price, Katell Berthelot

More Information

"Macedonians had a period of enslavement to Persians, Persians to Medes, Medes to Assyrians" (\$9I). Thus, even if not adhered to in a systematic manner, in every detail, or referred to in only a cursory way, the model of the four empires (preceding Rome) is a recurring pattern among Greek authors reflecting on the Roman Empire. ${ }^{5}$

\section{I.2 Philo's Personal Use of the Greek Model}

The first thing one needs to recall is that Philo never refers to the Book of Daniel, a point that strongly distinguishes him from Josephus. ${ }^{6}$ The scheme of the four or five empires found in Daniel 2 (in which the Assyrians are replaced by the Babylonians) therefore plays no role in his work. ${ }^{7}$ On the contrary, Philo refers to the great empires that preceded Rome in a way that recalls what can be found in Greek works.

Nonetheless, Philo does not merely repeat Greek topoi. He has his own perspective and selects only certain examples, while also adding new ones that are not usually found in the writings of Greek authors. In De Iosepho 134-I36, for instance, he starts with the example of Egypt's past glory, and probably has Pharaonic Egypt in mind as he speaks separately of the Macedonian kingdoms. Moreover, when tackling the case of the Macedonians, he singles out the Ptolemies as those who ruled over Egypt. ${ }^{8}$ This kind of "Egypt-centered" perspective appears again in Deus I75, another text that deals with the succession of empires, and one that shows that Philo was influenced by the place in which he lived. None of the Greek writers mentioned ever refer to Egypt as one of the important empires of the past, but instead remain faithful to the more "Eastern" perspective initiated by Herodotus. In Deus I74, we find another example of Philo's independence vis-à-vis the conventional Greek list of empires; here he evokes the past glory of Carthage (alluding to the Phoenician

5 It is also found in the works of Roman historians, possibly in Aemilius Sura's De annis populi Romani in the second century BCE (see n. 3), and as early as the first century BCE in the work of Pompeius Trogus, if the Epitoma of Justin can be trusted.

${ }^{6}$ See Biblia Patristica 1982. Although Philo's works consist merely of commentaries of the Pentateuch, they do quote from the prophetical books of the Hebrew Bible, but only in passing. On Josephus' understanding of Daniel's vision of the statue representing different empires, see Chapter 8 by Jonathan Davies in this volume.

7 The model of the four empires is considered of Oriental origin (see Gruen 1984: 315-16 and 328-29), though Arnaldo Momigliano claimed that the author of Daniel derived the idea from the Greeks. See Momigliano 1984.

${ }^{8}$ Ios. 136: "Where is the house of the Ptolemies, and the fame of the several successors (of Alexander) whose light once shone to the utmost boundaries of land and sea? ..." (transl. Colson, Loeb Classical Library (LCL), 205). 
Cambridge University Press

978-1-108-49481-6 - The Future of Rome

Edited by Jonathan J. Price, Katell Berthelot

More Information

\section{Philo on the Impermanence of Empires}

control of the Mediterranean), thereby pointing to the contemporary domination of Rome, which caused Carthage's power to vanish. His reference to Carthage obviously has to do with his Roman context. However, he does not really single out Carthage despite its having been the great enemy of Rome, but rather mentions it together with Ethiopia, Libya, and the kingdom of Pontus, etc. Philo's combined references to Egypt, Carthage, Libya, and Ethiopia may have to do with his "African" context.

It must be emphasized that Philo never mentions the Assyrians or the Medes, and thus never resorts to the Greek model of the four empires as such. Going one step further, one may state that Philo is concerned neither with the way(s) in which empires succeed each other from a historical point of view nor with the details of their political history. As we shall see, he is interested in past empires (be they Egypt, Persia, or the Macedonian kingdoms) merely as examples of a past glory that has gradually faded, sometimes in brutal fashion. Even more fundamentally, he turns to them for examples of the fact that human and terrestrial realities have no intrinsic permanence. The fact that the Persians historically preceded the Greeks is of no significance to him. Similarly, Philo does not reflect on the role that Persia or the Macedonian kingdoms played in the history of Israel.

Finally, insofar as Rome is concerned, Philo refers to the fall of the Hellenistic kingdoms several times without mentioning the Roman Empire by name, but merely alluding to its existence. ${ }^{9}$ Nowhere does Philo speculate about Rome being the fourth or the fifth empire, or affirm or suggest that it is supposed to be the last one in human history.

\subsection{Philo and the Comparisons of Different Empires}

\subsection{From Polybius to Aelius Aristides}

From Polybius onward, the chief reason for Greek writers' references to the great empires of the past seems to have lain in their need to compare these to Rome, to indulge in a kind of comparative "imperiology" dominated by the claim that this latest empire was of a superior kind, hitherto unseen in world history. An important recurrent element in all their comparisons of it to earlier empires is the emphasis they lay on the exceptional extent of the

\footnotetext{
9 See Quaest. Gen. 4.43; Deus 173; Ios. 134-136, and the analysis in $\$ 6.3$, as well as Berthelot 20II, in which I show that Philo did not agree with the discourse that celebrated the eternity of Roman rule and saw in Rome the final, everlasting empire.
} 
Cambridge University Press

978-1-108-49481-6 - The Future of Rome

Edited by Jonathan J. Price, Katell Berthelot

More Information

Roman Empire, from both a geographical and chronological point of view. The physical breadth of the empire seems the more striking of the two, but Greek writers generally drew a close association between its longevity and geographical scale, at least from the first century CE onward (in Polybius's time, it was obviously too early to celebrate the duration of Rome's control over the world).

Let us first look at the beginning of Polybius's Histories:

How striking and grand is the spectacle presented by the period with which I intend to deal, will be most clearly apparent if we set beside and compare with the Roman dominion the most famous empires of the past, those which have formed the chief theme of historians. Those worthy of being thus set beside it and compared are these. The Persians for a certain period possessed a great rule and dominion, but so often as they ventured to overstep the boundaries of Asia they imperiled not only the security of this empire, but their own existence. The Lacedaemonians, after having for many years disputed the hegemony of Greece, at length attained it but to hold it uncontested for scarce twelve years. The Macedonian rule in Europe extended but from the Adriatic region to the Danube, which would appear a quite insignificant portion of the continent. Subsequently, by overthrowing the Persian Empire they became supreme in Asia also. But though their empire was now regarded as the greatest geographically and politically that had ever existed, they left the larger part of the inhabited world as yet outside it. For they never even made a single attempt to dispute possession of Sicily, Sardinia, or Libya, and the most warlike nations of Western Europe were, to speak the simple truth, unknown to them. But the Romans have subjected to their rule not portions, but nearly the whole of the world and possess an empire which is not only immeasurably greater than any which preceded it, but need not fear rivalry in the future. ${ }^{1 \mathrm{O}}$

Although this passage clearly focuses on the exceptional geographical size of the Roman Empire, Polybius ends with a remark that suggests that its rule will be equally exceptional in terms of length for reasons that he explains throughout the Histories.

Writing during Augustus's principate, Dionysius of Halicarnassus is able to emphasize the stability of Roman rule in a new way, thus stating:

If anyone turns his attention to the successive supremacies both of cities and of nations, as accounts of them have been handed down from times past, and then, surveying them severally and comparing them together, wishes to determine which of them obtained the widest dominion and both in peace and war performed the most brilliant achievements, he will find that the

оo Histories I.2.I-7 (transl. by W. R. Paton, rev. by F. W. Walbank and Christian Habicht, LCL, 5-7). 
Cambridge University Press

978-1-108-49481-6 - The Future of Rome

Edited by Jonathan J. Price, Katell Berthelot

More Information

\section{Philo on the Impermanence of Empires}

supremacy of the Romans has far surpassed all those that are recorded from earlier times, not only in the extent of its dominion ( and in the splendour of its achievements - which no account has as yet worthily celebrated - but also in the length of time (тò $\mu \tilde{\eta}$ коs тоũ Xpóvou) during which it has endured down to our day. ${ }^{\text {II }}$

Dionysius goes on to prove his point by examining the length and geographical extent of the empires of the Assyrians, the Medes, the Persians, and the Macedonians. He repeats his conclusion in I.3.3-5:

But Rome rules every country that is not inaccessible or uninhabited, and she is mistress of every sea, not only of that which lies inside the Pillars of Hercules but also of the Ocean, except that part of it which is not navigable; she is the first and the only State recorded in all time that ever made the risings and the settings of the sun the boundaries of her dominion. Nor has her supremacy been of short duration, but more lasting than that of any other commonwealth or kingdom ... there is no nation, as I may say, that disputes her universal dominion or protests against being ruled by her. ${ }^{\mathrm{I}}$

Later, and with even sounder reasons, Appian similarly states in his preface that "No government down to the present time ever attained to such size and duration," and that its "boundary is the ocean both where the sun-god rises and where he sinks" (\$8). He thus falls back on the literary topos already used by Dionysius. ${ }^{13}$

Aelius Aristides, too, celebrates the extraordinary geographical breadth of the Roman Empire (Roman Oration, \$28), but also introduces a qualitative element linked to the very nature of Roman rule, which he considers even more significant for a proper appreciation of its exceptional character: "Vast and comprehensive as is the size of it, your empire is much greater for its perfection than for the area which its boundaries encircle" (\$29). ${ }^{I 4}$ By this he means that the power of Rome is not that of a despot, that Roman rule is wholeheartedly supported by all peoples who fall under it (a point already made by Dionysius), that its subjects are free men $(\$ 36)$, and that the Romans rule according to nature (\$9I). Logically enough, in \$29 Aelius goes on to state that "for the eternal duration of this empire, the whole civilized world prays all together." In \$108 he adds that "to compose the oration which would equal the majesty of your empire" would "require just about as much time as time allotted to the empire, and that would be all

${ }^{\text {II }}$ Roman Antiquities I.2.I, transl. by Earnest Cary, LCL, 7. On this passage see Alonso-Núñez I983.

${ }^{12}$ Transl. by Earnest Cary, LCL, II.

${ }^{13}$ For a more detailed analysis of the similarities and the differences between Dionysius and Appian, see Weißenberger 2002.

${ }^{14}$ The translation used for Aelius's Roman Oration is that in Oliver 1953. 
Cambridge University Press

978-1-108-49481-6 - The Future of Rome

Edited by Jonathan J. Price, Katell Berthelot

More Information

eternity." Aelius therefore contemplates the possibility, at least rhetorically, that Roman rule will last forever.

Finally, one should emphasize that in \$106, Aelius suggests that Hesiod was wrong to locate the golden race of men in the distant past. He points out that, in any case, the iron race ended when the Romans began ruling the oikoumene, implying therefore that their empire amounts to a new Golden Age. Aelius's discourse thus recalls motifs found in the writings of Latin poets before and during Augustus's principate, which considered Augustus's rule the beginning of a new Golden Age. ${ }^{\mathrm{IS}}$

\subsubsection{Philo's Praise of the Roman Imperial Order in the Legatio ad Gaium}

In general, Philo does not refer to great former empires in order to compare them and analyze their respective achievements and failures. Although he does sometimes juxtapose the customs and norms of the Persians, Greeks, and other peoples, he does not compare empires as such, probably because in his eyes, they were all fundamentally similar in their arbitrariness and volatility. ${ }^{16}$

In the Legatio ad Gaium, however, one finds a passage with a description of the empire's geographical expanse that seemingly recalls those of the Greek authors whose works we have examined so far. In it, Philo describes the situation of the Roman Empire at the onset of Caligula's reign and celebrates the achievements of Augustus and Tiberius, with particular emphasis on the pax Romana. First, he notes that Caligula received "the

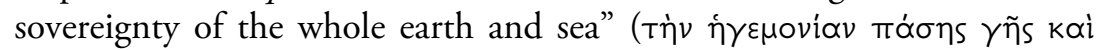
$\theta \propto \lambda \alpha$ ó $\sigma$, $\$ 8)$, and then describes the empire as:

A dominion not confined to the really vital parts which make up most of the inhabited world, and indeed may properly bear that name, a world

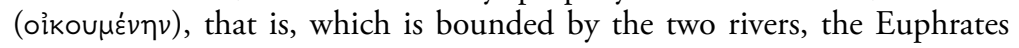
and the Rhine, the one dissevering (us) from the Germans and all the more brutish nations, the Euphrates from the Parthians and from the Sarmatians and Scythians, races which are no less savage than the Germans, but a

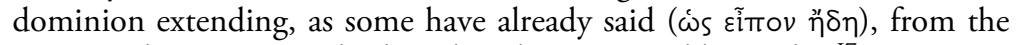
rising to the setting sun both within the ocean and beyond it. ${ }^{17}$

is The idea of an imminent Golden Age already appears in Virgil's Fourth Eclogue, as well as in later writings. See Chapter 2 by Brian Breed in this volume.

${ }^{16}$ See $\$ 6.3$.

${ }^{17}$ Legat. IO, transl. F. H. Colson, LCL, 7-9, slightly modified. See also Legat. I43-I47 and 309 for an encomium of the reign of Augustus and of the universal peace it brought about; these passages, however, entail no comparison with previous empires. 
Cambridge University Press

978-1-108-49481-6 - The Future of Rome

Edited by Jonathan J. Price, Katell Berthelot

More Information

\section{Philo on the Impermanence of Empires}

Philo seems to fully agree with the view that the world that deserves to be called oikoumene - the civilized world - stops at the Rhine and the Euphrates, beyond which only savage barbarians live. He thus equates the civilized world with the Roman Empire. ${ }^{18}$ By mentioning the Euphrates and the Rhine, the Germans and the Parthians, Philo refers to the boundaries of the Empire, which somehow undermines his later claim that the empire extends "from the rising to the setting sun both within the ocean and beyond it." As we have seen with the writings of Dionysius, this statement is actually a topos, as Philo himself admits with the words $\omega s$

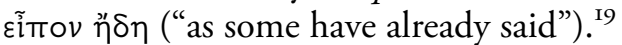

In the paragraphs that follow, Philo describes the first seven months of Caligula's reign and the universal joy that prevailed during this period and then compares them to the age of Saturn:

In these days the rich had no precedence over the poor, nor the distinguished over the obscure, creditors were not above debtors, nor masters above slaves, the times giving equality before the law. Indeed, the life under Saturn, pictured by the poets, no longer appeared to be a fabled story, so great was the prosperity and well-being, the freedom from grief and fear, the joy which pervaded households and people. (Legatio ad Gaium I3)

By comparing the beginning of Caligula's reign to the age of Saturn, i.e., to the Golden Age, Philo repeats ideas that had been in the air during Augustus's principate, and that would still be echoed in Aelius Aristides's Roman Oration. ${ }^{20}$

In short, this passage shows Philo reproducing a conventional discourse. Nonetheless, his reference to both the Germans and the Parthians, the chief threats to the Roman Empire, may be interpreted in at least two ways; not only is he emphasizing that the Empire encompasses the entire civilized world (the obvious meaning of his text), but he is also astutely pointing out the real limits of Roman rule despite claiming that these coincide with the entire world. We shall see that other references to the Parthians in Philo's work seem to entail a similar underlying message on the limits of Roman

${ }^{18}$ Hadas-Lebel 2012 : 63 concludes thus: "Philon, Juif de la Diaspora, n'a pas d'aspirations nationalistes ; dans sa cité d'Alexandrie, il se sent partie intégrante du grand Empire romain étendu aux dimensions de l'univers." For a different view, see Berthelot 20 II.

19 On this passage, see Niehoff 200I: II3-I8, who notes that "Philo's assumption of literally universal and unchallenged Roman dominion reflects imperial ideology" and that in his Res Gestae, Augustus had "elegantly passed over the fact that the Germans and Parthians had not been truly conquered" (Philo, II4; see Res Gestae 3:I, 6:I, 8:5, 26:3-4, 32:2, 34:I). On the idea of the Urbs as orbis terrarum, see Ovid, Fasti 2:684

${ }^{20}$ See n. I4. 
Cambridge University Press

978-1-108-49481-6 - The Future of Rome

Edited by Jonathan J. Price, Katell Berthelot

More Information

hegemony, not only in terms of geographical extent, but also in terms of duration. ${ }^{21}$

\subsection{Philo's Philosophical Reflections on Empires and Their Implications for the Future of Rome}

\subsection{The Debate on the Instability of Empires and the Role of Fortune}

Written at the beginning of the Hellenistic period, Demetrius of Phalerum's philosophical work On Fortune includes a passage on the instability of empires, which is quoted with approval by several later authors, such as Polybius and Diodorus. In a passage in Polybius (Histories 29.2I), Demetrius argues that Fortune (Tychè) is a free agent, who has "show[n] all people, by establishing the Macedonians in the prosperity that used to be the Persians', that it has lent these blessings to them as well until it arrives at a different decision concerning them." 22 Demetrius thus states that both Persian and Macedonian rule were gifts of Fortune, and that both had therefore been intrinsically unstable insofar as Fortune's decisions are always changing. Reflecting on Demetrius's statement, Polybius claims that it was, in fact, a prophetic utterance proven true by the Roman defeat of Perseus, king of Macedonia, at Pydna in I68 BCE.

Polybius thus seems to share Demetrius's perspective on the role played by Fortune in the growth and decline of empires. As far as Rome is concerned, however, Polybius's discourse is complex and ambiguous. In some passages of the Histories he seems to attribute the successes of Rome at least in part to Fortune, whereas in other passages he clearly emphasizes other factors, such as Rome's political institutions and the extraordinary discipline of its military. ${ }^{23}$ Towards the end of his life, he did in fact predict

${ }^{21}$ The Legatio itself contains only one more reference to the Parthians, who Caligula himself describes as ruling the peoples of the East. See Legat. 256 (in Caius's letter to Petronius): "You concern yourself with the institutions of the Jews, the nation which is my worst enemy; you disregard the imperial commands of your sovereign. You feared their great numbers. Then had you not with you the

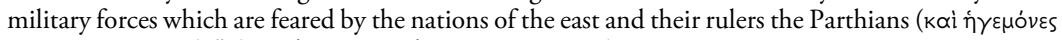

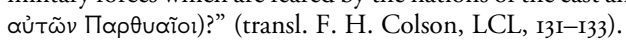

${ }^{22}$ See Fortenbaugh and Schütrumpf 2000: 149 ( $\left.{ }^{\circ} 82 \mathrm{~A}\right)$. See also Diodorus Siculus, Historical Library 3I.IO.

${ }^{23}$ On this issue in Polybius, see in particular Ferrary $1988: 265-76$, esp. 27I: "A ceux qui attribuaient à la Fortune l'extraordinaire succès des Romains, Polybe n'opposait pas l'idée d'un empire éternel voulu par le Destin : il montrait que les Romains avaient méthodiquement réalisé un projet raisonnable bien que sans précédent, car fondé sur une juste estimation de leurs possibilités." On Polybius and the rise of Rome, see also Walbank 1957-79: vol. I, I6-26; Walbank 1972: 157-83; Walbank 1974: I-38; Walbank 2002: 243-92; Pédech 1964: 331-54; Eckstein 1995: 194-236; and Guelfucci 2oıo. Walbank, Pédech, and Eckstein maintain that for Polybius, Tychē, along with other 
Cambridge University Press

978-1-108-49481-6 - The Future of Rome

Edited by Jonathan J. Price, Katell Berthelot

More Information

\section{Philo on the Impermanence of Empires}

the decline of Rome, but connected it to social, political, and moral factors rather than to the changing will of Fortune.

If an author admits that Fortune played a role in the rise of the Roman Empire, does this mean that he also believes that it will pass away just as its predecessors did? Some Greek authors who were critical of Roman imperialism clearly express this view and are censured by Dionysius of Halicarnassus for doing so. ${ }^{24}$ According to Dionysius, Roman successes have been due not to mere Fortune, but rather to divine providence (pronoia). This view makes it possible for him to claim outstanding longevity for Rome in contrast to the decline and decay experienced by earlier empires.

Plutarch is another interesting Greek voice in this debate. In his treatise On the Fortune of the Romans, he wonders whether it is Virtue (Arete) or Fortune $(T y c h \bar{e})$ who is the main cause of Rome's achievements. On the ethical level, Tyche symbolizes the elements or circumstances faced by the moral agent, which he or she cannot influence, whereas Aretè represents the inner disposition of the individual that depends on him or herself. ${ }^{25}$ In Plutarch's work, both Tychè and Aretē, in fact, enhance Rome's superiority. In $\$$ I, Plutarch already asks:

Who, then, will not declare, when Rome shall have been added to the achievements of one of the contestants, either that Virtue is a most profitable thing if she has done such good to good men, or that Good Fortune is a thing most steadfast if she has already preserved for so long a time that which she has bestowed? ${ }^{26}$

In other words, due to Rome's lasting dominion over the oikoumene, the argument that Roman successes are a gift of Fortune necessarily entails that she is not as unstable and uncertain as generally argued. It thus means that Fortune can be recognized as playing a role in the ascent of Rome without being loaded with the usual pejorative connotations associated with Tyché. Moreover, Plutarch actually affirms that in the case of Rome, Fortune and Virtue have joined forces:

factors, played a major role in the ascension and supremacy of Rome - not as mere chance but as a teleologically oriented force. Polybius's references to Tyche $\vec{e}$ s role are not entirely consistent with his rational explanation of Rome's rise. See also Jonathan Price's Chapter 5 in the present volume, where he argues that Tychè changes from a guiding to an irrational force in Polybius as the Greek historian changes his mind about Rome.

${ }^{24}$ See Rom. Hist. I.4.2. ${ }^{25}$ See Frazier 20IO: III-XXIII, esp. XIV.

26 Transl. by Frank Cole Babbitt, LCL, 323. 
Cambridge University Press

978-1-108-49481-6 - The Future of Rome

Edited by Jonathan J. Price, Katell Berthelot

More Information

Even as Plato asserts that the entire universe arose from fire and earth as the first and necessary elements, that it might become visible and tangible, earth contributing to it weight and stability, and fire contributing colour, form, and movement; but the medial elements, water and air, by softening and quenching the dissimilarity of both extremes, united them and brought about the composite nature of Matter through them; in this way, then, in my opinion, did time lay the foundation for the Roman State and, with the help of God ( $\mu \varepsilon \tau \dot{\alpha} \theta \varepsilon \circ \tilde{)}$ ), so combine and join together Fortune and Virtue that, by taking the peculiar qualities of each, he might construct for all mankind

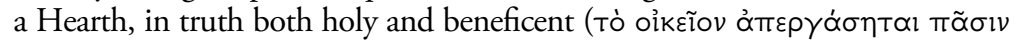

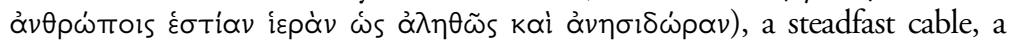
principle abiding for ever, 'an anchorage from the swell and drift,' as Democritus says, amid the shifting conditions of human affairs. ${ }^{27}$

Thus, in Plutarch's opinion, the foundation of Rome and the extent of its domination do not lack a providential dimension ( $\mu \varepsilon т \dot{\alpha} \theta \varepsilon \circ \tilde{)})$. It is true that in \$I, Plutarch wonders whether the city of Rome owes its existence to the work of Tyche or Pronoia, which reminds us of the debate in which Dionysius of Halicarnassus was involved. However, the first paragraph makes it unclear whether Plutarch's question reflects his concern for the stability of the Roman Empire, or is simply one of terminology. ${ }^{28}$ In any case, $\$ 2$ shows that Plutarch viewed Rome's fate as being at least in part the result of a divine scheme, and the Roman state as something particularly stable. $^{29}$

Later, in $\$_{4}$, Plutarch describes Fortune’s actions and her particular relationship with Rome as follows:

Fortune, when she had deserted the Persians and Assyrians, had flitted lightly over Macedonia, and had quickly shaken off Alexander, made her way through Egypt and Syria, conveying kingships here and there; and turning about, she would often exalt the Carthaginians. But when she was approaching the Palatine and crossing the Tiber, it appears that she took off her wings, stepped out of her sandals, and abandoned her untrustworthy

27 On the Fortune of the Romans 2, transl. by Frank Cole Babbitt, LCL, 326.

${ }^{28}$ In a different yet similar way, when Livy writes about the difficult beginnings of Roman history, he mentions Fate as a determining factor in the development of the empire, with no negative connotation: "But Fate (fatum) was resolved, I suppose, upon the founding of this great city, and the beginning of the mightiest of empires, next after that of the gods" (Rom. Hist. I.4.I; transl. B. O. Foster, LCL, I7). Here, Fate is more or less equivalent to divine providence.

${ }^{29}$ Swain 1989 argues that Plutarch sees divine providence as being involved in Roman history: "Plutarch did not simply muddle what happened with what was destined to happen. The present order and good government of the world was pleasing to the divine in his eyes, and indeed divine interest was obvious in the natural world around him also" (276). Babut 1969 is more cautious in his assessment of the role that Plutarch assigns to providence in history. 
Cambridge University Press

978-1-108-49481-6 - The Future of Rome

Edited by Jonathan J. Price, Katell Berthelot

More Information

\section{Philo on the Impermanence of Empires}

and unstable globe. Thus did she enter Rome, as with intent to abide, and in such guise is she present to-day, as though ready to meet her trial. ${ }^{30}$

Plutarch builds on the scheme of the succession of empires to create a personal version that does not merely mention the Macedonians, but refers specifically to the Ptolemies and the Seleucids as well as the Carthaginians, the former enemies of Rome, ${ }^{3 \mathrm{I}}$ in order to show that Fortune has established a different relationship with Rome, a city in which she seems willing to abide permanently.

All in all, by discussing the respective roles of Arete and Tychè in the rise of Rome, Plutarch does not mean to undermine Roman successes or suggest that the Roman Empire will disappear as its predecessors did. On the contrary, Rome enjoys a very special relationship with Tyche that thus leaves open the possibility of long-lasting stability. At least, this is the point of view reflected in Plutarch's On the Fortune of the Romans, which may have been a scholarly exercise meant to facilitate his integration into Roman society. ${ }^{32}$ As Françoise Frazier rightly notes, this work is probably insufficient to credit Plutarch with a real "philosophy of history." 33

\subsubsection{Philo's Position in the Debate}

Unlike Plutarch, Philo sees Fortune as something consistently negative; contrary to pronoia, it cannot be considered an expression of God's will, ${ }^{34}$ God's blessing or God's punishment, ${ }^{35}$ even if it does not represent an independent power at work in the universe, insofar as God controls everything. Nowhere does Philo say that God's providence (pronoia) is at work in the Roman Empire, or that the Empire enjoys divine support. Yet, he also never explicitly affirms that the Romans rule the world thanks to a fickle and unfair Fortune. However, at the very beginning of the Legatio - a work in which he deals with the threats against the Jews and the Temple of Jerusalem under Caligula, as well as with providential salvation - he shares some general thoughts on Tychè, and elsewhere (Legat. 284), has Agrippa speak about Caligula's destiny and power in terms of Tyche.

${ }^{3}$ On the Fortune of the Romans 4, transl. by Frank Cole Babbitt, LCL, 332.

${ }^{31}$ In their reflections on fallen empires of the past, Philo and Plutarch both mention the Ptolemies, the Seleucids, and the Carthaginians, but nowhere does Philo speak about Fortune in positive terms or state that Fortune or Providence shall remain on Rome’s side. See \$6.3.2.

${ }^{32}$ See Frank Cole Babbitt, LCL, 320. ${ }^{33}$ See Frazier 20I0: XIX. ${ }^{34}$ See Spec. 2.23I.

35 It seems that in this respect Philo differs from Josephus, for whom Fortune can sometimes be an expression of God's will. There is one apparent exception in Philo's writings (Deus I76); see further discussion in this chapter. 
Cambridge University Press

978-1-108-49481-6 - The Future of Rome

Edited by Jonathan J. Price, Katell Berthelot

More Information

Furthermore, Philo's work offers us at least three quite telling instances of his reflections on the instability of empires. The first example is found in the final section of the treatise on the subject "That God is immutable," Quod deus sit immutabilis (from \$I40 onward), where Philo comments on Genesis 6:I2, which states that "all flesh had corrupted his way upon the earth." Philo understands "his way" as referring to God's way, which lies in wisdom. This is the way taken by Israel, who leaves behind all the worldly goods that correspond to the kingdom of Edom and are unreal. To the earthly and worthless man, symbolized by Edom, Israel (or Philo) says:

I7I For in very truth "the matter" which has so engaged your zeal is absolutely "nothing." I72 Or do you think that aught of mortal matters has real being or subsistence, and that they do not rather swing suspended as it were on fallacious and unstable opinion, treading the void and differing not a whit from false dreams? I73 If you care not to test the fortunes of individual men, scan the vicissitudes, for better and worse, of whole regions and nations. Greece was once at its zenith, but the Macedonians took away its power. Macedonia flourished in its turn, but when it was divided into portions it weakened till it was utterly extinguished. I74 Before the Macedonians fortune smiled on the Persians, but a single day destroyed their vast and mighty empire, and now Parthians rule over Persians, the former subjects over their masters of yesterday. The breath that blew from Egypt of old was clear and strong for many a long year, yet like a cloud its great prosperity passed away. What of the Ethiopians, what of Carthage, and the parts towards Libya? What of the kings of Pontus? I75 What of Europe and Asia, and in a word the whole civilized world? Is it not tossed up and down and kept in turmoil like ships at sea, subject now to prosperous, now to adverse winds? 176 For circlewise moves [or: dances] the divine

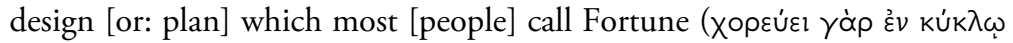

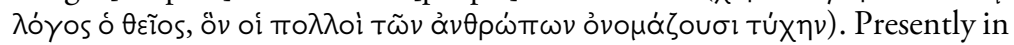
its ceaseless flux it makes distribution city by city, nation by nation, country by country. (Deus I7I-I76) $)^{36}$

In short, "mortal matters," which include glory, power, prosperity, and the like, have no intrinsic stability and are even devoid of reality; they are comparable to dreams. The fortune of nations is as unstable and fugitive as that of individuals. Prosperity will give way to adversity. For Philo, however, a divine plan lies beyond what most people call Fortune. This is an important claim, which seems to indicate that he did develop a certain theology of history. Moreover, the end of the passage may be interpreted as meaning that Rome's present rule owes its existence to the movement of

${ }^{36}$ Transl. Colson, LCL, 95-97, slightly modified. 
Cambridge University Press

978-1-108-49481-6 - The Future of Rome

Edited by Jonathan J. Price, Katell Berthelot

More Information

\section{Philo on the Impermanence of Empires}

the divine logos. Philo seems to think that Roman rule is not the result of mere chance, insofar as God controls everything on earth; at the same time, however, it cannot be described as a divine gift as that would imply that divine providence works on behalf of the Romans. In Philo's work, providence seems to be covenantal: it sustains the cosmos or benefits Israel, and thus corresponds to the covenant with Noah after the flood, on the one hand, and to the covenant with Israel, on the other. ${ }^{37}$ This may explain why in this case, when referring to God's plan, Philo uses the term logos rather than pronoia.

The fact that this discourse on the instability of fortune (according to the common sense of the term, with reference to prosperity, glory etc.) is addressed to the wretched Edom raises an important question: Did "Edom," the terrestrial kingdom, symbolize Rome in Philo's eyes? The identification of Rome with Edom or Esau is only attested in Jewish sources from the late first century CE on. It appears allusively in apocalyptic writings, and later in rabbinic literature, but mostly from the fourth century CE on (despite a few occurrences in Tannaitic works). ${ }^{38}$ It is unclear whether this identification was already common in the early first century, or present in Philo's work. There is no real way of answering this question conclusively. Still, the fact that Philo addresses his speech on the instability of empires to Edom is quite interesting, as is the fact that in accordance with the biblical narrative, he explicitly states in $\$$ I8o that the divine logos shall stop Edom and those who follow him. According to $\$ 176$, it is this divine logos that distributes good fortune to cities and nations.

Another passage by Philo that deals with the instability or impermanence of empires appears in De Iosepho $134-136$, within a more general discussion on the theme of "life is a dream," to which Philo adds the idea based on the story of Joseph - that the political man is the interpreter of dreams. Turning at one point to empires, Philo writes:

I34 For nothing at all anywhere has remained in the same condition; everywhere all has been subject to change and vicissitudes (тротаĩs $\delta \dot{\varepsilon}$ kai $\mu \varepsilon \tau \alpha \beta \circ \lambda \alpha i$ s). I35 Egypt once held the sovereignty over many nations, but now is in slavery. The Macedonians in their day of success flourished so greatly that they held dominion over all the habitable world, but now they pay to the tax-collectors the yearly tributes imposed by their masters. I36 Where is the house of the Ptolemies, and the fame of the several successors [i.e., of Alexander] whose light once shone to the utmost

\footnotetext{
37 See Berthelot 20II: I77-79.

${ }^{38}$ The bibliography on Rome as Esau or Edom is vast; see the seminal article Cohen 1967; and Berthelot 2016 for a recent review of the bibliography.
} 
Cambridge University Press

978-1-108-49481-6 - The Future of Rome

Edited by Jonathan J. Price, Katell Berthelot

More Information

boundaries of land and sea? Where are the liberties of the independent nations and cities, where again the servitude of the vassals? Did not the Persians once rule the Parthians, and now the Parthians rule the Persians? So much do human affairs twist and change, go backward and forward as on the draught-board. (De Iosepho 134-136) 39

In this case, Philo is not concerned about the translatio imperii as such, or about any kind of chronological succession of historical events. What he wants to emphasize is the impermanence of wordly realities, which, like scales, go up and down, ${ }^{40}$ appearing and disappearing. Wisdom, he claims, lies in being aware of this intrinsic impermanence of both wordly powers and individual fortunes. ${ }^{4 \mathrm{I}}$

Zealous to demonstrate his point, Philo lacks rigor and exaggerates the geographical extent of the Macedonian kingdoms, which never conquered Europe or North Africa (beyond Egypt) and thus could not be described as

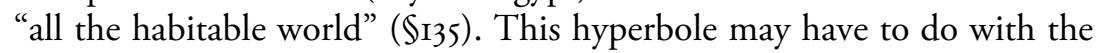
unnamed successor of these kingdoms, namely, the Roman Empire, which by contrast, was viewed as holding dominion over "all the habitable world," the oikoumene, in quite an exaggerated manner even in Philo's time. ${ }^{42}$ The rule according to which all things are subject to change and vicissitude also applies beyond the realm of Rome, to the Parthian kingdom; it is truly universal. It is also firm and stable. Thus the rule of continuous change and vicissitude is eternal. Logically enough, those,

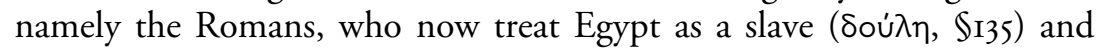
are the present masters of the Macedonians, shall one day live under the dominion of other masters. In other words, Rome's power and glory too shall pass as did those of its predecessors.

Still, one could argue that in De Iosepho I34, Philo speaks about the way in which the world used to run (in the past tense) until the Romans achieved world domination, and that things are different now. In order to strengthen the interpretation proposed above, let us look at a passage in the Quaestiones in Genesim, which, in André-Jean Festugière's view, closely resembles Demetrius of Phalerum's On Fortune: ${ }^{43}$

39 Transl. Colson, LCL, 205.

${ }^{40}$ Compare Ios. 136 with Deus 177-I78. Munnich 20II: 176 argues that "le Quod deus souligne la relativité des empires, alors que le De Josepho insiste sur leur disparition." However, it seems to me that both emphasize the transient nature of all things, point to the disappearance of past empires,

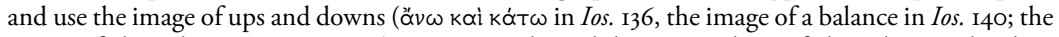
image of the tide in Deus $177-178$ ) to suggest that while certain things fade, others make their appearance, and that when some people go down, others go up.

${ }^{41}$ See Ios. I4O and I44 for the use of tyche, in the plural in this case.

42 See Philo's Legatio 8-IO and \$6.2. ${ }^{43}$ See Festugière 1949: 523-25. 
Cambridge University Press

978-1-108-49481-6 - The Future of Rome

Edited by Jonathan J. Price, Katell Berthelot

More Information

\section{Philo on the Impermanence of Empires}

When the Persians ruled land and sea, who expected that they would fall? And again, when the Macedonians (ruled)? But if anyone had dared to say so, he would most certainly have been laughed at as a fool and a simpleton. And no less necessary a change awaits those nations that opposed them, though they have become illustrious and conspicuous in the meantime; so that those at whom (others) laughed are beginning to laugh (at them), while those who laughed are becoming (an object of) laughter for thinking that things which are by nature mobile and changeable are immobile and unalterable. (Quaestiones in Genesim 4.43) ${ }^{44}$

The Greek original of this passage is only partly preserved. The Greek word for "change" is probably metabolè, as similar passages confirm. That wordly goods and situations are not permanent, but subject to multiple changes, is a recurring theme in Philo's work, as we have seen. ${ }^{45}$

The most striking aspect of this passage lies in the fact that Philo unambiguously foretells the fall of Rome. The sentence "no less necessary a change awaits those nations that opposed them, though they have become illustrious and conspicuous in the meantime," which refers to those who overcame the Macedonians, that is, the Romans, leaves no doubt as to the latter's fate. Like the empires that preceded them, the Roman one will ultimately fall and be replaced by another power.

\subsubsection{Philo's Theological Perspective on History and the Future of Rome}

Of the three texts on the impermanence of empires, the passage in Deus 176 quoted above is the only one in which Philo refers to the action of the divine logos in history. That he had a certain "theology of history" is apparent from other passages in his work, however, and from his so-called historical treatises, In Flaccum and Legatio ad Gaium.

Let me first quote a passage from Book 3 of De Specialibus Legibus, in the section dealing with the prohibition of murder. After dealing with the murder of free men, Philo tackles the issue of the murder of slaves (or servants):

I37 Servants rank lower in fortune, but in nature can claim equality with their masters, and in the law of God the standard of justice is adjusted to

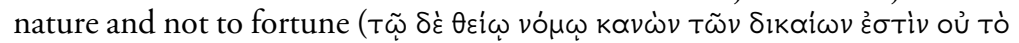

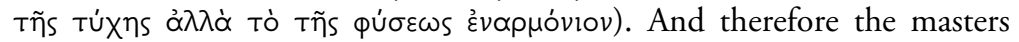
should not make excessive use of their authority over slaves by showing arrogance and contempt and savage cruelty. For these are signs of no

44 Transl. Marcus, LCL, 3I8. $\quad 45$ See Munnich 2011. 
Cambridge University Press

978-1-108-49481-6 - The Future of Rome

Edited by Jonathan J. Price, Katell Berthelot

More Information

peaceful spirit, but of one so intemperate as to seek to throw off all responsibility and take the tyrant's despotism for its model. 138 . He who has used his private house as a sort of stronghold of defiance and allows no freedom of speech to any of the inmates but treats all with the brutality created by native or perhaps acquired hatred for his fellow-men, is a tyrant (túpavvós) with smaller resources. 139. By his use of them he gives proof that he will not stay where he is, if he gets more wealth into his hands, for he will pass on at once to attack cities and countries and nations, after first reducing his own fatherland to slavery, a sign that he will not deal gently with any of his other subjects (úmínool). I40. Such a one must clearly understand that his misconduct cannot be prolonged or widely extended with immunity, for he will have for his adversary justice, the hater of evil, the defender and champion of the ill-used, who will call upon him to give an account for the unhappy condition of the sufferers. (De Specialibus Legibus 3.137-I40) ${ }^{46}$

Philo's starting point lies in the biblical laws pertaining to the murder of a slave (Exod 2I:20-2I). However, he switches from the abuse of individuals to the oppression of countries and nations $\left(\varepsilon^{\prime} \theta \nu \eta\right)$. The figure of the tyrant, known from Greek political writings, is merged here with that of the Hellenistic king or, more probably, with that of the Roman imperator, who conquers and subdues many nations. Although nowhere does Philo advocate the suppression of slavery as such, ${ }^{47}$ he condemns the arrogance and the cruelty that may characterize a slave master and warns that punishment shall fall on those who abuse and mistreat others, be it in the private sphere or at the level of an entire empire. In other words, he is implicitly warning the Roman governors or emperors who are currently ruling over the Jews to be careful, lest they be punished by God, who is the only true source of justice (Dikē).

This is actually the point that Philo makes in In Flaccum - Flaccus perishes miserably due to his responsibility for the riots against the Jews in Alexandria - as well as in Legatio, where Caligula's murder is the punishment he suffers for attempting to erect a statue of himself in the Temple of Jerusalem. Significantly, as we saw above, the Legatio opens with some general thoughts on the opposition between Tyche and Nature that recall those in De Specialibus Legibus 3.137. How can we be so blind, Philo asks, as to hold "fortune, the most unstable of things, to be the most unchangeable, [and] nature, the most constant, to be the most insecure? ... The reason is that, having no forethought for the future, we are ruled by the present, following erratic sense-perception

${ }^{46}$ Transl. F. H. Colson, LCL, 563-565.

47 In line with other Greek, Roman and Jewish sources of the period; see Urbach 1964 . 
Cambridge University Press

978-1-108-49481-6 - The Future of Rome

Edited by Jonathan J. Price, Katell Berthelot

More Information

\section{Philo on the Impermanence of Empires}

rather than unerring intelligence." ${ }^{8} 8$ Some people are thus led to believe that there is no divine providence for Israel $\left(\$ \$_{3}-4\right)$. Philo uses the story of Caligula precisely to show that such assumptions are wrong: whereas Caligula's amazing prosperity (described at length at the beginning of the Legatio) was put to an end - implying that all things are ruled by Fortune ${ }^{49}$ - Israel was saved, thanks to God's providential care for His people. ${ }^{50}$

In short, from Philo's perspective, the only human community that shall endure all the vicissitudes of life is Israel. The Roman Empire shall fade away, as does every worldly power. Roman rule may last longer if emperors truly attempt to govern in a just manner and respect the right of Israel to live according to its ancestral laws. However, it may end sooner than most people think if the Romans behave unjustly and challenge God's providential care for Israel. In the end, God is the one who will put an end to the Empire.

All in all, Philo's allusive reflections on the future of the Roman Empire do not differ substantially from those of Josephus or the rabbis. They may all be said to share the following vision: divine providence has not abandoned Israel; Rome rules today but shall one day collapse. Ultimately, the spiritual rule of Israel shall prevail. ${ }^{5 \mathrm{I}}$

\section{Acknowledgment}

This research has been funded by the European Research Council (ERC) under the European Union's Seventh Framework Program (FP/200720I3)/ERC Grant Agreement no. 6I4 424. It has been conducted within the framework of the ERC project Judaism and Rome, under the auspices of the Centre National de la Recherche Scientifique (CNRS) and AixMarseille University, UMR 7297 TDMAM (Aix-en-Provence, France).

\footnotetext{
${ }^{48}$ Legat. I-2, transl. F. H. Colson, LCL, 3. ${ }^{49}$ Cf. Legat. 284.

so Philo's treatment of the episode is comparable to Josephus' in Antiquities I8, insofar as both consider that all historical events are ultimately controlled by God. On this aspect of Josephus' work, see Chapter 8 by Jonathan Davies' in this volume. Both Philo and Josephus also suggest that what is good for Israel is also good for Rome, as Caligula was likewise a disaster for the Romans.

${ }^{51}$ On this idea in Philo's work, see Berthelot 20II: I84-86, and the bibliography therein.
} 